Review

\title{
Use of Genetically Modified Mesenchymal Stem Cells to Treat Neurodegenerative Diseases
}

\author{
Robert D. Wyse ${ }^{1}$, Gary L. Dunbar ${ }^{1,2}$ and Julien Rossignol ${ }^{1,3, *}$ \\ 1 Field Neurosciences Institute Laboratory for Restorative Neurology, \\ Brain Research and Integrative Neuroscience Center, Program in Neuroscience, \\ Central Michigan University, Mount Pleasant, MI 48859, USA; \\ E-Mails:wyse1r@cmich.edu (R.D.W.); dunba1g@cmich.edu (G.L.D.) \\ 2 Field Neurosciences Institute, Saginaw, MI 48604, USA \\ 3 College of Medicine, Central Michigan University, Mt. Pleasant, MI 48859, USA \\ * Author to whom correspondence should be addressed; E-Mail: rossi1j@cmich.edu; \\ Tel.: +1-989-774-3405; Fax: +1-989-774-1215.
}

Received: 2 December 2013; in revised form: 18 December 2013 / Accepted: 14 January 2014 / Published: 23 January 2014

\begin{abstract}
The transplantation of mesenchymal stem cells (MSCs) for treating neurodegenerative disorders has received growing attention recently because these cells are readily available, easily expanded in culture, and when transplanted, survive for relatively long periods of time. Given that such transplants have been shown to be safe in a variety of applications, in addition to recent findings that MSCs have useful immunomodulatory and chemotactic properties, the use of these cells as vehicles for delivering or producing beneficial proteins for therapeutic purposes has been the focus of several labs. In our lab, the use of genetic modified MSCs to release neurotrophic factors for the treatment of neurodegenerative diseases is of particular interest. Specifically, glial cell-derived neurotrophic factor (GDNF), nerve growth factor (NGF), and brain derived neurotrophic factor (BDNF) have been recognized as therapeutic trophic factors for Parkinson's, Alzheimer's and Huntington's diseases, respectively. The aim of this literature review is to provide insights into: (1) the inherent properties of MSCs as a platform for neurotrophic factor delivery; (2) the molecular tools available for genetic manipulation of MSCs; (3) the rationale for utilizing various neurotrophic factors for particular neurodegenerative diseases; and (4) the clinical challenges of utilizing genetically modified MSCs.
\end{abstract}


Keywords: mesenchymal stem cells; genetic engineering; Parkinson's; Alzheimer's; Huntington's; neurodegenerative diseases; transplantation; glial cell-derived neurotrophic factor (GDNF); brain derived neurotrophic factor (BDNF); nerve growth factor (NGF)

\section{Aims of Review}

This review provides information on the current developments and challenges of MSCs (mesenchymal stem cells) as a cell-based intervention for neurodegenerative diseases, in particular Parkinson's, Alzheimer's and Huntington's disease. Additionally, rationale for the use of MSCs as a biological device to deliver therapeutic molecules targeting disease pathology is provided. Furthermore, the molecular methods to modify MSCs for the enhancement of their therapeutic utility are discussed in detail.

\section{MSC Background}

Derived from a wide range of sources, MSCs are capable of long-term survival and replication in culture [1]. The primary sources utilized from which of MSCs are derived include bone marrow (BM), adipose tissue (ADI) [2], and umbilical cord blood (UCB) [3]. Till and McCulloch [4] have described the in vivo clonal nature of bone marrow cells, while Friedenstein and colleagues [5] provided an in vitro assay to evaluate the clonogenic potential of these cells, identifying them as colony-forming units-fibroblastics (CFU-Fs). A standardized set of criteria to define MSCs was set forth by The International Society for Cellular Therapy in an attempt to standardize MSC nomenclature. These criteria mandate that the MSCs be plastic adherent, express CD105, CD73 and CD90, while lacking CD45, CD34, CD14, CD11b, CD79 $\alpha$, CD19, or human leukocyte antigen (HLA) DR expression. In addition, MSCs must differentiate into osteoblasts, adipocytes and chondroblasts in vitro [6]. Although these criteria are generally accepted, a variety of factors, such as source of the cell [1], isolation protocols [7], culturing methods [8], and lack of a specific marker [9], create a challenge to define MSC unambiguously. The title of MSCs, which was popularized by Caplan [10], has become rather nebulous ensuing a debate on the appropriate use of the identifiers, stem or stromal, in the title [11]. With the indistinctive title of MSC many laboratories have assigned different names for their preparations, such as multipotent adult progenitor cells [12], unrestricted somatic stem cells [13], and multidifferentiated mesenchymal progenitor cells [14] as a means to appropriate title cell preparations. Use of different isolation methods and culturing techniques give rise to a variety of cell populations with unique characteristics [15]. In order to make accurate comparisons of the efficacy of the therapeutic uses of MSCS, further standardization that specifies the reporting of phenotypic cell markers and genetic expression profiles are needed.

With the challenge of standardization aside, MSCs serve as readily accessible cell populations that are easily amplified [16] and contain several beneficial capabilities. The low immunogenicity and immunomodulatory capacity of MSCs may be seen as the most valuable features of these cells. The immunomodulatory effect of transplanted MSCs is most apparent in the treatment of graft versus host disease [17-19]. The exact mechanisms of immunomodulation are currently unknown, but a large 
repository of evidence [20] suggests that, through an interferon- $\gamma$ initiated pathway [21], MSCs can secrete indoleamine 2,3-dioxygenase and prostaglandin E2 [22], leading to the suppression of both T-cell [23] and natural killer cell proliferation.

The chemotaxic properties of MSCs have gained attention recently, as MSCs have been observed to migrate through the internal environment towards sites of inflammation [24]. The homing responses of MSCs are directed by a host of chemokines and growth factors and can be harnessed and enhanced through pre-exposure to inflammatory cytokines [25] or genetic modification, prior to transplantation. One signaling system that has been utilized for this purpose is the signaling factor stromal cell-derived factor-1 (SDF-1), which is expressed in areas of inflammation in the brain [26,27]. When the chemokine receptor type 4 (CXCR4), which responds to SDF-1, is overexpressed in MSCs, it increases homing functions for disease-specific areas related to acute kidney injury [28], myocardial infarction [29], glioblastoma [30], and ischemic stroke [31]. This homing system has been successfully used in other studies without direct genetic overexpression of chemokine receptors produced by MSC pre-conditioning, maintenance in hypoxic conditions (low $\mathrm{O}_{2}, 5 \%$ ), or treatment with factors that mimic hypoxia [32]. The up-regulation of receptors in MSCs through hypoxic exposure has been related to an increase in therapeutic efficacy following systemic [33] or intranasal [34] administration in animal models ischemic stroke. MSCs that were maintained in a hypoxic environment had a higher migration response in vitro to growth factors, chemokines, and inflammatory cytokines, compared to MSCs maintained in normoxic conditions [35]. The hypoxic maintenance of MSCs provides a valuable tool to increase the homing capacity of MSCs as a therapeutic intervention. However, the homing capacity of MSCs is diminished through extended passaging [36], or when cultured beyond confluency [37].

A rising concern with the therapeutic use of MSCs is the mode of delivery. Through chemotaxis, systemic delivery has shown promise in the ability of MSCs to home in on areas of injury [38]. However, there is often a wide dispersal of MSCs throughout many other organs beyond the area of injury. Generally, administration into the peripheral venous system results in an initial concentration of MSCs in the lungs, followed by a gradual targeting of the injured area [39]. However, combinatory treatment of heparin with MSCs injection has been shown to circumvent the initial concentration of cells in the lungs following inter-venous injection [40], and an intra-arterial injection close to the site of injury has been shown to increase homing efficacy [41]. While intra-arterial injections may increase the number of engrafted cells, this delivery method also generates an enhanced risk of vascular occlusion [41]. The method of delivery, local, intra-arterial, or intravenous should be tailored to the goals of the therapeutic intervention while considering the potential risks of each method.

Although systemic delivery of MSCs is noninvasive, the blood brain barrier (BBB) presents a significant challenge to effective treatment in central nervous system disorders [42]. Several studies have shown that MSCs were not able to cross the BBB following systemic delivery $[43,44]$ due to a variety of challenges [45]. However, there is growing evidence that MSCs may be able to cross the BBB in sufficient numbers to elicit a therapeutic benefit [42,45]. For example, ADI MSCs have been shown to cross the BBB following intravenous injection in a mouse model of Alzheimer's disease [46]. In addition, intra-arterially delivered BM mononuclear cells migrated into the brain of ischemic stroke patients within two hours following their administration [47]. This ability for MSCs to cross the BBB following systemic delivery has been observed in several other studies $[42,48]$, 
suggesting that systemic delivery of MSCs may be a feasible method of delivery. While observations of MSCs crossing the BBB have been made, this ability may be dependent upon disruption or dysfunction of the BBB [46]. Additionally, the state of BBB function, through the progression of a disease or injury [49] may impact the therapeutic efficacy of systemic administrated MSCs.

Upon reaching the area of interest, MSCs seem to release factors that ameliorate the degenerating or diseased environment. The paracrine signaling of transplanted MSCs has been cited as the primary mechanism of recovery in a wide range of studies [50]. As discussed above, MSCs have been shown to possess immunomodulatory functions and secrete a wide range of neuroprotective proteins [51]. It has been observed that MSCs can secrete brain derived neurotrophic factor (BDNF), nerve growth factor (NGF), vascular endothelial growth factor (VEGF), and hepatocyte growth factor (HGF) [52]. Further analyses have revealed that sub-populations of MSCs express higher levels of such factors [53]. These beneficial factors secreted by MSCs (since termed the secretome) can be observed when injecting conditioned medium, but only when the fraction is greater than $10 \mathrm{kDa}$, as observed in a model of spinal cord injury [54] and myocardial infarction in mice [55] and pigs [56]. These studies highly implicate the role of MSCs in paracrine signaling, and provide an opportunity for experimenters to develop new methods of genetically enhancing the therapeutic function of MSCs.

\section{Genetic Delivery Using MSCs}

Recently, a significant attention has been placed on the therapeutic potential of extracellular vesicles, in particular exosomes, that are approximately 30-200 $\mathrm{nm}$ in size [57]. These exosomes were originally considered solely responsible for the removal of aberrant materials [58], but now have been shown to carry a variety of critical molecules, including mRNA, miRNA proteins, lipids, mitochondrial DNA, and genomic DNA [59,60]. Exosomes are formed by the invagination of the endosomal membrane, released after fusion of multivesicular bodies with the plasma membrane [61] and are involved in cell-to-cell communication in a wide variety of cells and systems [62]. The endosomal signaling of MSCs has been shown in multiple studies to be at least partially responsible for the therapeutic effect of transplanted MSCs [63], thus further implicating the therapeutic role of signaling from MSCs.

Researchers have utilized the secretome of MSCs in order to deliver therapeutic molecules in non-invasive manners that can target areas of degeneration. The endogenous incorporation of a particular protein into exosomes can be guided through chimeric infusion of the protein of interest to the $\mathrm{C} 1 \mathrm{C} 2$ domain of MFG-E8/lactadherin protein in place of the EGF domain [64]. This technique results in an exosome-bound protein that has been shown to be more effective than a soluble counterpart in the reduction of tumor size, resulting from a directed immune response [65]. This technique has also been used to specifically target the brain by replacing the EGF domain with the rabies viral glycoprotein (RVG) peptide resulting in systemically administered MSC-derived exosomes that cross the BBB. These exosomes then deliver exogenously loaded Beta-secretase 1 (BACE1) siRNA, which can knock down BACE1 (Alzheimer's disease related protein), mRNA, and protein levels in neurons, microglia and oligodendrocytes [66].

Overexpression of a therapeutic gene has also been shown to result in exosomal-mediated transfer of the therapeutic mRNA and protein to the desired target [67]. While general overexpression is not 
precise, specific targeting of RNA to exosomes may be possible through the modification of the 3'-UTR of a therapeutic sequence to include a 25 nucleotide segment that contains a binding site for microRNA-1289, which in turn mediates the packaging of mRNA into exosomes [68].

Pretreatment of MSCs under specific conditions, has been shown to modify the secretome of MSCs and change their efficacy in treatment. Xin and colleagues [69] observed the efficacy of pre-treating MSCs with ischemic brain extracts. The pre-treated MSCs showed an increased expression of microRNA-133b that was able to be transferred to neurons and astrocytes through exosomes, resulting in an increase of neurite length and branching of treated neurons [69].

Through genetic manipulation the basal therapeutic immunomodulatory, chemotaxic, and signaling functions of MSCs can be enhanced in order to develop a specific therapy designed to target a particular disease mechanism. A variety of methods are available to introduce exogenous genes to be expressed by MSCs. The most frequently utilized method is the viral vector.

\subsection{Lentivirus \& Retrovirus}

A major advantage of using MSCs for stem cell therapies is the ease at which they can be manipulated, either through changes in culture conditions or virally mediated genetic engineering. Lentivirus- and retrovirus-based delivery systems are efficient and are capable of integrating into the genome ensuring the long-term expression of the transgene [70]. Retroviral transfection of the deficient IL-2 receptor $\gamma$ (IL2RG) in autologous hematopoietic stem cells, ex vivo, has been clinically utilized in the treatment of X-linked severe combined immunodeficiency (SCID) [71] and the treatment of other diseases [72]. However, it was observed in a recent study that the use of the retrovirus vector as led to insertional mutagenesis, resulting in activation of proto-oncogenes in four of fifteen patients [73]. The lentivirus, which is part of the retrovirus family is capable of transfecting dividing and non-dividing cells [74]. Clinical success utilizing a lentiviral vector has been observed in the treatment of X-linked adrenoleukodystrophy in the same fashion as X-linked SCID [75], but without any reported complications. Lentiviral gene therapy is generally accepted to be safer than use of a retrovirus because of the measures taken to remove viral components and the extensive pre-clinical testing that has been conducted [76]. Although the use of the lentiviral vector causes fewer insertional mutations, this procedure is not without risk. Bokhoven and colleagues [77] developed a cell culture assay to identify insertional mutagenesis in key genes and found no differences between the rate of mutagenesis of a retrovirus and a lentivirus, albeit these were mediated through different mechanisms [77].

\subsection{Adenovirus}

Adenoviruses do not integrate into the host genome and can infect both dividing and non-dividing cells, with transient expression in dividing cells and long-term expression in non-dividing cells. First generation adenoviruses are highly immunogenic, and in one case, has led to the fatal immune response of a patient treated for ornithine transcarbamylase deficiency [78]. Adeno-associated viruses (AAVs) have a lower immunogenicity and are the first vector approved for gene therapy in the Western world, designed to treat lipoprotein lipase deficiency [79]. Thus, AAV-based gene delivery is generally considered to be a safer alternative then lentiviral and retroviral gene delivery, primarily due 
to its lack of integration, although problems of immunogenicity are still of concern [80]. While the AAV does not functionally insert the gene into the genome, random homologous and heterologous recombination into the host genome can occur [81]. Even though transfection of MSCs with adenoviruses or AAVs does not lead to prolonged gene expression, intra-arterially administered human BM-MSCs that were transduced to express interferon- $\beta$ (IFN- $\beta$ ) via an adenovirus had sufficiently lasting effects to increase the survival time of rats with induced glioblastomas [82]. Subsequently, MSCs have also been utilized as a vector for delivery of adenovirus in multiple glioblastoma studies $[83,84]$.

\subsection{Non-Viral Agents}

Non-viral mediation of gene transduction into MSCs is an increasingly attractive avenue for gene therapy, because these methods circumvent complications of viral-based gene insertion. Alternative techniques include electroporation [85], lipofection [86], nucleofection [87], as well as the use of calcium phosphate nanoparticles [88], nanoneedles [89], and polysaccharides [90-93]. The source of MSCs has been shown to influence the efficiency of transduction [94], so the use of these procedures necessitates appropriate testing and investigation into which cell type is most effective for non-viral gene delivery.

Zinc finger nuclease (ZFN) [95], transcription activator-like effector nuclease (TALEN) [96], and the CRISPR/Cas system [97] are new tools for genetic modification. Each of these tools can be designed to safely target a specific sequence in determined loci and initiate a double strand break of DNA, initiation endogenous DNA repair, which allows for the insertion of the therapeutic gene [98]. Intraperitoneal administration of human BM, UCB, and ADI MSCs resulted in relatively long-term elevation of erythropoietin plasma levels when ZFN methods were utilized to overexpress the erythropoietin gene [99]. These methods have rarely been investigated with MSCs, but may prove to be an invaluable resource for genetic engineering, as they are being increasingly utilized in many other applications [98].

Development of human artificial chromosomes (HACs) is another promising avenue of non-viral mediated transgene expression in MSCs, due to their proven stability. Through truncation of the 21st chromosome and introduction of a Cre-loxP gene insertion target, HACs capitalize upon the cell cycle for stable expression, reduce the risk of aberrant integration, offer control over copy number, and can carry an extremely large payload (of up to $10 \mathrm{Mb}$ ), allowing for entire genes to be transduced [100]. Hoshiya and colleagues [101] observed that HACs, carrying the entire dystrophin gene (of about $2.4 \mathrm{Mb}$, including both coding and regulatory portions), were stable in human immortalized MSCs for 100 population doublings. Stable expression of transgenes in MSCs with HACs has been verified in other studies as well [102,103]. Additionally, Kinoshita and colleagues [104] observed, in a rat model of glioma, that an injection of human MSCs, transduced with a HAC carrying the thymidine kinase gene, as well as an infusion of ganciclovir, resulted in the reduction of glioma volume.

The US Food and Drug Administration does not currently approve gene therapy for the general public, as there have been several clinical challenges when using this method [105]. The pursuit of safe gene therapy vectors and treatment of a wide range of diseases through ex vivo manipulation of the 
patient cells and re-administration is encouraged by Szybalski [106], who originally demonstrated genetic transformation.

\section{Genetically Engineering MSCs for Parkinson's Disease}

Primary symptoms of Parkinson's disease (PD) include asymmetric resting tremor, rigidity, and bradykinesia [107]. Ten percent of those diagnosed with Parkinson's disease are of the familial type, which is associated with multiple mutations in several genes [108]. The age of onset, which can be influenced by familial history, usually occurs during the third or fourth decade of life [108]. Degeneration of dopaminergic neurons in the substantia nigra is the identified cause of symptoms, which do not arise until fifty percent of nigral neurons are lost and there is an eighty percent decrease of striatal dopamine [109]. The dysfunctions of mitochondrial activity, inflammation, oxidative stress, and protein misfolding have all been identified as antecedents of PD pathology. However, these changes may be the result of other downstream effects that might be the primary cause of PD [110]. Intraneuronal Lewy bodies, containing alpha-synuclein aggregation, are found throughout the brain and are pathological hallmarks of PD [111]. The most frequent treatment for PD is levodopa (L-DOPA), which increases dopamine levels, leading to improved motor function, but this therapy frequently results in L-DOPA-induced dyskinesia [112]. Surgical ablation of targets within the thalamus and pallidus were utilized to treat PD symptoms in the past, but deep brain stimulation (DBS) is the currently preferred therapy [113]. While DBS is intrusive, as electrodes must be placed in the same target areas used in ablation techniques, a benefit is that the electrodes can be adjusted to provide the most efficacious treatment for the patient [113]. However the current treatments for PD only mitigate the symptoms and do not treat the underlying pathology, hence the need for alternative therapies is evident [114].

Use of glial derived neurotrophic factor (GDNF) was first identified by Lin and colleagues [115] as a potential treatment for PD because of its ability to increase the dopamine uptake in, and the survival of, embryonic ventral midbrain dopaminergic neurons [116]. The mechanisms of GDNF protection are still unknown, but the GDNF family receptor-1 $\alpha$ signal is transduced by Ret, a membrane receptor protein tyrosine kinase [117]. There are three additional paralogs of the GDNF ligand and receptor genes in humans, which have been investigated for their therapeutic value, along with multiple orthologs in other vertebrates [118]. Ret stimulation, via GDNF, cascades to activate the PI3K/Akt and MAPK/Erk pathways [119]. Activation of the PI3K/Akt pathway has been implicated in GDNF-mediated neuronal survival [120,121]. Given that ninety-five percent of GDNF-expressing neurons in the striatum are parvalbumin-positive interneurons [122], targeting means of activating endogenous populations of these cell types or culturing them for subsequent transplantation may serve as an effective means for potential treating PD.

Clinical trials using GDNF for treating PD have produced mixed results. A double-blind study, in which a range of 25-4,000 micrograms of GDNF was delivered via a catheter into the right ventricle of PD patients did not yield improvements on the Unified Parkinson's Disease Rating Scale (UPDRS); in addition, several side effects were initially observed, but were subsequently resolved following the discontinuation of treatment [123]. Another trial utilized bilateral, direct pump infusion of GDNF to the putamen of PD patients, and yielded a 39\% decrease in off-medication UPDRS scores, a $64 \%$ 
reduction of L-DOPA induced dyskinesias, and a $28 \%$ increase of dopamine in the putamen 18 months following treatment, as measured by $\left[{ }^{18} \mathrm{~F}\right]$ dopa positron emission tomography [124]. In addition, the unilateral infusion of GDNF into the putamen of ten PD patients proved equally beneficial for at least six months [125]. It is important to note that the successful trials using infusion of GDNF into the putamen were open-label, while the double-blind study did not yield positive outcomes [126]. However, the lack of beneficial results in double-blind studies may have been the result of inadequate diffusion of GDNF [127], rather than experiment bias on placebo effects.

With mixed clinical results and challenges of infusion, ex vivo cell-based strategies to deliver GDNF has gained recent attention as an appropriate alternative [128]. As shown in Table 1, use of MSCs for delivering trophic factors for treating PD and other neurodegenerative diseases has provided promising results. An early pilot study, conducted by Venkataramana and colleagues [129], in which autologous BM-MSCs were injected unilaterally into the lateral wall of the lateral ventricle in seven PD patients (one million cells per $\mathrm{kg}$ ), yielded a $22.9 \%$ for off-drug and a $31.7 \%$ for on-drug improvement of UPDRS scores in three of the seven patients, and while producing no adverse events. This study was extended by bilaterally injecting a dose of two million BM-MSCs per kg from healthy donors into twelve PD (8 early-, 4 late-onset) patients, resulting in UPDRS score improvement of $17.92 \%$ for on-drug and $31.21 \%$ for off-drug in early-onset patients, with no improvements identified in late-onset patients [130]. The positive therapeutic results and the lack of serious adverse responses during these pilot studies, suggests that treatments using MSCs may have significant clinical utility for PD.

The engineering of MSCs to express GDNF has received much attention recently. MSCs transduced with a retrovirus to express GDNF increased dopaminergic neuron sprouting when transplanted in the striatum at four days prior to 6-OHDA injection in a rat model of PD [131]. Glavaski-Joksimovic and colleagues [132] observed a decrease in amphetamine-induced rotations following a unilateral transplantation of human MSCs (expressing GDNF and transiently pre-differentiated with a Notch plasmid) into the striatum at one week following unilateral 6-OHDA administration into the same rat striatum. In another study, Sadan and colleagues [133] transplanted human MSCs primed with mitogens (basic fibroblast growth factor, epidermal growth factor, and platelet derived growth factor) that had a fivefold increase of BDNF and twofold increase of GDNF expression compared to unprimed MSCs and were more efficacious than unprimed MSCs in ameliorating behavioral and dopamine deficits in a rat striatal 6-OHDA lesion model. Using another approach, intrastriatal injections of MSCs, transduced with a lentivirus to overexpress GDNF, were given one week before a lactacystin lesion of the medial forebrain bundle and significantly increased striatal dopamine levels, while reducing apomorphine-induced rotations [134]. Furthermore, Ren and colleagues [135] transplanted autologous BM-MSCs, that were genetically modified to overexpress GDNF, into the striatum and substantia nigra of MPTP-treated non-human primates. The transplants of these cells increased levels of dopamine in the striatum and improved contralateral limb function, but did not prevent the loss of nigral dopaminergic neurons. 
Table 1. Selected studies utilizing MSCs for the treatment of neurodegenerative diseases.

\begin{tabular}{|c|c|c|}
\hline Disease & Species, Model & Note \\
\hline PD & Human & $\begin{array}{l}\text { Symptom reduction with no adverse effects following unilateral } \\
\text { BM-MSC transplant [129]. }\end{array}$ \\
\hline PD & Human & $\begin{array}{l}\text { Improvement in early-stage patients following bilateral BM-MSC } \\
\text { transplant [130]. }\end{array}$ \\
\hline PD & Rat, Intrastriatal 6-OHDA & $\begin{array}{l}\text { GDNF-BM-MSCs enhanced tyrosine hydroxylase labeling and } \\
\text { dopaminergic neuronal sprouting in striatum [131]. }\end{array}$ \\
\hline PD & Rat, Intrastriatal 6-OHDA & $\begin{array}{l}\text { GDNF-Notch-BM-MSCs decreased amphetamine-induced } \\
\text { rotation [132]. }\end{array}$ \\
\hline PD & Rat, Intrastriatal 6-OHDA & $\begin{array}{l}\text { Mitogen treated human BM-MSCs reduced behavioral and } \\
\text { dopamine deficits [133]. }\end{array}$ \\
\hline $\mathrm{PD}$ & $\begin{array}{l}\text { Rat, Medial forebrain } \\
\text { bundle lactacystin lesion }\end{array}$ & $\begin{array}{l}\text { GDNF-BM-MSCs increased striatal dopamine levels and reduced } \\
\text { apomorphine-induced rotation [134]. }\end{array}$ \\
\hline PD & Non-human primate, MPTP & $\begin{array}{l}\text { Unilateral transplant of GDNF-BM-MSCs into striatum and } \\
\text { substantia nigra increased contralateral motor performance and } \\
\text { increased dopamine levels at area of transplant [135]. }\end{array}$ \\
\hline $\mathrm{AD}$ & $\begin{array}{l}\text { Mouse, Acute } \\
\text { amyloid- } \beta \text { aggregate }\end{array}$ & $\begin{array}{l}\text { Levels of amyloid- } \beta \text { were reduced following BM-MSC } \\
\text { administration [136]. }\end{array}$ \\
\hline $\mathrm{AD}$ & $\begin{array}{l}\text { Mouse, Acute } \\
\text { amyloid- } \beta \text { aggregate }\end{array}$ & $\begin{array}{l}\text { Delivery of human UCB-MSCs reduced behavioral deficits and } \\
\text { toxic aggregation presumably through immunomodulation [137]. }\end{array}$ \\
\hline $\mathrm{AD}$ & $\begin{array}{l}\text { Rat, Acute } \\
\text { amyloid- } \beta \text { aggregate }\end{array}$ & $\begin{array}{l}\text { NGF-BM-MSCs provided enhanced therapeutic effects over non } \\
\text { treated BM-MSCs }[138,139] \text {. }\end{array}$ \\
\hline HD & Mouse, YAC128 & $\begin{array}{l}\text { BDNF-MSCs ameliorated rotorod deficits and restored striatal } \\
\text { neuronal loss [140]. }\end{array}$ \\
\hline
\end{tabular}

\section{Genetically Engineering MSCs for Alzheimer's Disease}

The primary symptoms of $\mathrm{AD}$ are cognitive dysfunction and dementia, which include a wide range of other distressing emotional and behavioral concerns [141]. An estimated 35.6 million people were affected with Alzheimer's disease (AD) worldwide in 2010 [142] and the prevalence is expected to quadruple by 2050, with 1 in 85 people living with AD [143]. The Alzheimer's Association currently estimates that 5.4 million Americans have AD [144].

Investigations into familial $\mathrm{AD}$ have identified dominant mutations of the amyloid precursor protein (APP), SorL1, and presenilin 1 and 2. These mutations account for five percent of AD diagnoses [145]. Several other genes have been identified as increasing the risk of AD [146], especially the epsilon 4 allele of the apolipoprotein E (APOE) gene. Ninety-one percent of homozygous carriers for APOE 4 develop $\mathrm{AD}$ at a mean onset of 68 years of age, $47 \%$ of heterozygotes at 76 years, and $20 \%$ for non-carriers at 84 years [147]. The AD-related genes directly or indirectly interact with the function of APP and its cleaved constituents, amyloid beta 1-40 $\left(\mathrm{A} \beta_{1-40}\right)$ and $A \beta_{1-42}$, or with the tau protein, which in their aggregated forms, produce amyloid plaques [148] and neurofibrillary tangles [149], the characteristic hallmarks of $\mathrm{AD}$. It is uncertain if plaques and tangles are causative or protective, but they are observed in conjunction with glial responses, as well as neuron and synaptic loss. Plaques are generally found throughout the cortex and tangles are thought to progress from the entorhinal cortex, to the hippocampal subfields and then spread to the amygdala, association cortex, and throughout the 
neocortex, respectively [150]. Observations of a reduction of neurons in the basal forebrain cholinergic nuclei $(\mathrm{BFChN})$ and reduced levels of choline acetyltransferase, acetylcholine, and acetylcholinesterase (AChE) in the hippocampus and neocortex led to the development of the cholinergic hypothesis of $\mathrm{AD}$ [151]. The Food and Drug Association (FDA) has approved AChE inhibitors for treatment of mild to moderate $\mathrm{AD}$. Memantine, a $N$-methyl-D-aspartate receptor agonist, has also been approved for treatment of moderate to severe $\mathrm{AD}$ [152]. These pharmacological interventions have been shown to provide only palliative benefits, partially delaying the progression of the disease, but are generally well tolerated [153].

However, because current $\mathrm{AD}$ treatments focus on symptoms related to neurotransmitter systems and do not target underlying pathologies, there is a clear need for more targeted interventions [154]. In attempts to focus on disease pathology, a variety of small molecule inhibitors have been identified that minimize the fibril formation of $\mathrm{A} \beta$ [155] and tau [156], but these drugs have faced many challenges in clinical trials [157]. Similar attempts with immunotherapy, targeted at plaques and tangles, are underway. This approach is targeted to diffuse aggregates, but overarching concerns of developing autoimmunity still need to be addressed [158]. Given the widespread prevalence of the disease and the lack of safe treatments that target the pathology, the development of new therapeutic strategies for $\mathrm{AD}$ is a critical need.

One such strategy involves the use of, nerve growth factor (NGF). Given that reduced retrograde transport of NGF from the hippocampus to the BFChN in $\mathrm{AD}$ patients was reported by Mufson, Conner, and Kordower [159], much attention has been given to modulating two levels of this molecules as a potential therapy for AD. NGF has a high affinity for tropomyosin kinase receptor A (TrkA), but a low affinity for the non-selective neurotrophin receptor p75 (P75NTR) [160]. TrkA signaling promotes survival, primarily through Ras activation of the PI3K\AKT pathway, although there are many other identified signaling pathways [161]. NGF signaling is mediated by TrkA and P75NTR interactions, whereby both pro-survival or apoptotic-regulatory signaling can occur [162]. The relationship of these receptors is important in AD pathology, as a reduction of TrkA, but not P75NTR, in BFChN neurons leads to increased behavioral symptomology [163,164] and A $\beta$ pathology [165]. These receptor relationships develop a time course of $\mathrm{AD}$ pathology, whereby NGF serves as a protective molecule at first, but then engages in degenerative responses [166]. With evidence of recovery in pre-clinical models [167,168], and an increasing understanding of the variables involved in the relationship between NGF and AD pathology [169], there is growing interest in the efficacy of NGF for treating AD [170].

Due to the inability of NGF to cross the BBB [171], initial trials were conducted using direct administration in the brain. In an early single-subject study, an AD patient was given intraventricular administration of murine recombinant NGF over three months which resulted in improvement of verbal episodic memory, but also caused significant weight loss [172]. Side effects, including back pain and weight loss, were observed in a similar trial of three AD patients, which was terminated early because no noticeable clinical improvements were apparent [173]. The pain response following NGF treatment is a result of the role NGF plays in the inflammatory response [174]. The nociceptive challenge of NGF treatment is being addressed by development of mutant NGF proteins that selectively activate TrkA receptors, but not P75NTR. These mutant NGF proteins may lead to an 
increased therapeutic potential via their agonist effects on TrkA receptors, without the concomitant pain and other adverse effects with P75NTR activation [175,176].

While direct infusion of NGF has had complications, a clinical trial of eight AD patients utilizing autologous fibroblasts, engineered to express NGF, were transplanted into the nucleus basalis of Meynert which produced NGF expression in grafts, a reduced decline or improvement of Mini-Mental Status Examination scores, a reduced decline of the Alzheimer Disease Assessment Scale-Cognitive subcomponent, and an increase in glucose activity in several areas receiving cholengergic input from transplant site [177]. These improvements were observed without adverse reactions to the NGF for twenty two months [177]. A phase II clinical trial of this method is currently open [178]. The treatment of AD with MSCs has not been studied directly in clinical trials, but results of some pre-clinical research are available.

Transplants of BM-MSCs have been shown to have considerable promise for treating AD (see Table 1). Transplants of BM-MSCs have been reported to reduce A $\beta$ through microglial activation in an acute $\mathrm{A} \beta$-induced mouse model of $\mathrm{AD}$ [136]. Lee and colleagues [137] transplanted human UCB-MSCs at three different time periods into the hippocampus of a transgenic mouse model of AD, observing improvements in the Morris-water-maze task and reductions in A $\beta$ and tau aggregation, presumably mediated through immunomodulation.

A proposed mechanism of this UCB-MSC mediated protection is through release of soluble intracellular adhesion molecule-1 which increases neprilysin, an A $\beta$-degrading enzyme, in microglia [179]. Using another source of MSCs, Katsuda and colleagues [180] also identified that ADI-MSCs directly secrete neprilysin. Following their observations of a therapeutic effect of BM-MSC when transplanted into the hippocampus of an acute $A \beta$-induced rat model [138], $\mathrm{Wu}$ and colleagues [139] used lipofection techniques to overexpress NGF in MSCs. These investigations observed an enhanced therapeutic effect of the NGF-transduced MSCs, transplanted in the same manner, to reduced memory deficits in the Morris-water-maze task.

\section{Genetically Engineering MSCs for Huntington's Disease}

The primary characteristics of Huntington's disease (HD) are choreic movement, along with emotional and cognitive disturbances, which generally develop at forty to fifty years of age, progressing for ten to twenty years, eventually resulting in death [181]. Prevalence of HD is 5.70 per 100,000 in Europe, North American, and Australia [182]. The cause of HD is a heritable autosomal dominant mutation, that exists as a polyglutamine (CAG) repeat within the first exon of the IT15 gene on the fourth chromosome within region p16.3 [183]. The disease has been identified to progress in conjunction with degeneration of medium spiny neurons within the striatum, specifically the caudate nucleus and putamen [184]. HD symptomology is observed when CAG repeats are greater than 36 and genetic anticipation has been associated with paternal transmission, with increased instability above 46 repeats [185]. The direct role of the huntingtin protein is still unknown, but the CAG repeat loci is an important feature, as this protein contains huntingtin, EFP3, PP2A, and TOR1 (HEAT) consensus areas, suggesting that the it is highly involved in protein-to-protein interactions, given that other proteins possessing a HEAT complex have been identified to be involved with regulatory cytoplasmic properties in eukaryotic cells [186]. In addition to the HEAT complexes, there are several protease 
cleavage sites, which are believed to lead to the toxic fragments [187], found as intranuclear inclusions and cytoplasmic aggregates. These aggregates are hallmarks of HD and have been shown to correlate with the progressive neurodegeneration [188]. A large body of evidence suggests that the HD aggregates reflect deficits in the ubiquitin-proteasome system, given toxic aggregates are labeled with ubiquitin, but are not sufficiently cleared [189]. However, there is many other hypotheses, including excitotoxicity, proteolysis, protein misfolding, autophagy, and mitochondrial dysfunctions, have also been implicated in the pathology of HD [190].

One characteristic of HD, that has received considerable attention recently is that reduced levels of BDNF are found in the striatum of HD patients [191]. BDNF is anterogradely transported to the striatum primarily from the neocortex but also from the pars compacta, amygdala, and central medial thalamic nucleus [192]. The lower BDNF levels in the striatum are partially due to a loss of function of the wild-type huntingtin protein, that inhibits repressor element 1 /neuron-restrictive silencer element (RE1/NSRE), which, in turn, silences the BDNF exon II promoter [193]. In addition to transcriptional influences on BDNF, the mutant huntingtin protein adversely affects proper BDNF transport and secretion, as wild-type huntingtin assists with the vesicle transport of BDNF along microtubules by forming a complex with huntingtin-associated protein I and the p150Glued subunit of dynactin [193].

Currently, there is no cure for HD, and only palliative treatments are available. In the past 10 years, several drugs have been investigated in clinical trials with no new approvals [194]. Treatment focuses on symptoms [195] and the only therapy currently available for HD is tetrabenazine, which selectively depletes monoamines particularly in the striatum resulting in less movement-related symptoms [196]. Pre-clinical investigations have shown that the use of small-interfering RNAs (siRNAs) which reduce the levels of both mutant and wild-type huntingtin, have, nonetheless, been shown to reduce histological and behavioral deficits in rodents [197-199] and in non-human primates [200,201]. MSCs transduced with a lentivirus to express siRNA targeted at mutant huntingtin has provided encouraging results, in vitro, as 50\% of mutant huntingtin is knocked down in HD affected neurons, but technical challenges have prevented a robust in vivo effect [202].

Exogenous administration of BDNF is another area being explored in the development of HD therapies. BDNF, which is an agonist for tropomyosin kinase receptor B (TrkB), is important in synaptic plasticity [203] and neuronal survival [204]. BDNF has been shown to provide trophic support and influence differentiation of striatal GABAergic neurons in vitro [205,206]. Administration of BDNF to rat neuronal cultures containing mutant huntingtin is neuroprotective [207]. In addition, partial striatal protection has been observed in vivo, when BDNF was delivered directly to the striatum of R6/1 mice [208].

Work in our lab [140] has shown that BM-MSCs that are modified using a retrovirus to overexpress NGF or BDNF, can produce a 6.8-fold increase in BDNF production and 4.6-fold increase in NGF over non-transfected MSCs. The genetically modified MSCs were then bilaterally transplanted into the striatum of YAC mice at four months of age. Behaviorally, clasping was reduced in all groups that received MSCs, regardless of the cell type, and deficits on the rotorod task were ameliorated in the group receiving BDNF-modified MSCs. Striatal NeuN positive cell counts were restored to wild-type levels in BDNF-MSC treated mice. Our preclinical findings clearly demonstrate that MSCs, transduced with BDNF, provide behavioral and histological improvement over MSCs that have not been genetically engineered. From these findings, Wheelock and colleagues [209] are expanding this 
research and beginning clinical trials utilizing genetically engineered human MSCs that overexpress BDNF for treatment of HD. The pre-cellular therapy observation study is currently enrolling [210].

\section{Conclusions}

The history of both clinical and pre-clinical trials reveal that MSCs provide considerable promise as therapeutic agents [211-213], especially as sources for producing or vectors for delivering neurotrophic factors [214] for the treatment of neurodegenerative diseases (see Table 1).

Research into developing safe methods to deliver therapeutic MSCs [215] should be a priority, as complications and mortality have plagued previous attempts at intracranial transplantations of therapeutic cells [177]. To maximize the potential therapeutic benefit, attention must be placed on the culturing conditions of MSCs prior to transplantation, as these factors greatly affect the utility and safety of MSCs [216,217]. Continued investigation into the use of various tissue sources, approaches to genetic manipulation, methods of administration, and clinical challenges facing therapeutic MSCs are needed to facilitate the development of new therapies neurodegenerative diseases.

\section{Acknowledgments}

This project was supported by funds from the John G. Kulhavi and from the Field Neurosciences Institute (Saginaw, MI, USA).

\section{Conflicts of Interest}

The authors declare no conflict of interest.

\section{References}

1. Da Silva Meirelles, L.; Chagastelles, P.C.; Nardi, N.B. Mesenchymal stem cells reside in virtually all post-natal organs and tissues. J. Cell Sci. 2006, 119, 2204-2213.

2. Zuk, P.A.; Zhu, M.; Mizuno, H.; Huang, J.; Futrell, J.W.; Katz, A.J.; Benhaim, P.; Lorenz, H.P.; Hedrick, M.H. Multilineage cells from human adipose tissue: Implications for cell-based therapies. Tissue Eng. 2001, 7, 211-228.

3. Bieback, K.; Kern, S.; Klüter, H.; Eichler, H. Critical parameters for the isolation of mesenchymal stem cells from umbilical cord blood. Stem Cells Dayt. Ohio 2004, 22, 625-634.

4. Till, J.E.; McCulloch, E.A. A direct measurement of the radiation sensitivity of normal mouse bone marrow cells. Radiat. Res. 1961, 14, 213-222.

5. Friedenstein, A.J.; Chailakhjan, R.K.; Lalykina, K.S. The development of fibroblast colonies in monolayer cultures of guinea-pig bone marrow and spleen cells. Cell Tissue Kinet. 1970, 3, 393-403.

6. Dominici, M.; le Blanc, K.; Mueller, I.; Slaper-Cortenbach, I.; Marini, F.; Krause, D.; Deans, R.; Keating, A.; Prockop, D.; Horwitz, E. Minimal criteria for defining multipotent mesenchymal stromal cells. The International Society for Cellular Therapy position statement. Cytotherapy 2006, 8, 315-317.

7. Ho, A.D.; Wagner, W.; Franke, W. Heterogeneity of mesenchymal stromal cell preparations. Cytotherapy 2008, 10, 320-330. 
8. Hagmann, S.; Moradi, B.; Frank, S.; Dreher, T.; Kämmerer, P.W.; Richter, W.; Gotterbarm, T. Different culture media affect growth characteristics, surface marker distribution and chondrogenic differentiation of human bone marrow-derived mesenchymal stromal cells. BMC Musculoskelet. Disord. 2013, doi:10.1186/1471-2474-14-223.

9. Boxall, S.A.; Jones, E. Markers for characterization of bone marrow multipotential stromal cells. Stem Cells Int. 2012, doi:10.1155/2012/975871.

10. Caplan, A.I. Mesenchymal stem cells. J. Orthop. Res. Off. Publ. Orthop. Res. Soc. 1991, 9, 641-650.

11. Lindner, U.; Kramer, J.; Rohwedel, J.; Schlenke, P. Mesenchymal stem or stromal cells: Toward a better understanding of their biology? Transfus. Med. Hemotherapy Off. Organ Dtsch. Ges. Transfusionsmedizin Immunhamatologie 2010, 37, 75-83.

12. Jiang, Y.; Jahagirdar, B.N.; Reinhardt, R.L.; Schwartz, R.E.; Keene, C.D.; Ortiz-Gonzalez, X.R.; Reyes, M.; Lenvik, T.; Lund, T.; Blackstad, M.; et al. Pluripotency of mesenchymal stem cells derived from adult marrow. Nature 2002, 418, 41-49.

13. Kögler, G.; Sensken, S.; Airey, J.A.; Trapp, T.; Müschen, M.; Feldhahn, N.; Liedtke, S.; Sorg, R.V.; Fischer, J.; Rosenbaum, C.; et al. A new human somatic stem cell from placental cord blood with intrinsic pluripotent differentiation potential. J. Exp. Med. 2004, 200, 123-135.

14. Seshi, B.; Kumar, S.; Sellers, D. Human bone marrow stromal cell: Coexpression of markers specific for multiple mesenchymal cell lineages. Blood Cells Mol. Dis. 2000, 26, 234-246.

15. Bühring, H.-J.; Battula, V.L.; Treml, S.; Schewe, B.; Kanz, L.; Vogel, W. Novel markers for the prospective isolation of human MSC. Ann. N. Y. Acad. Sci. 2007, 1106, 262-271.

16. Lennon, D.P.; Caplan, A.I. Isolation of human marrow-derived mesenchymal stem cells. Exp. Hematol. 2006, 34, 1604-1605.

17. Le Blanc, K.; Rasmusson, I.; Sundberg, B.; Götherström, C.; Hassan, M.; Uzunel, M.; Ringdén, O. Treatment of severe acute graft-versus-host disease with third party haploidentical mesenchymal stem cells. Lancet 2004, 363, 1439-1441.

18. Le Blanc, K.; Frassoni, F.; Ball, L.; Locatelli, F.; Roelofs, H.; Lewis, I.; Lanino, E.; Sundberg, B.; Bernardo, M.E.; Remberger, M.; et al. Developmental Committee of the European Group for Blood and Marrow Transplantation Mesenchymal stem cells for treatment of steroid-resistant, severe, acute graft-versus-host disease: A phase II study. Lancet 2008, 371, 1579-1586.

19. Resnick, I.B.; Barkats, C.; Shapira, M.Y.; Stepensky, P.; Bloom, A.I.; Shimoni, A.; Mankuta, D.; Varda-Bloom, N.; Rheingold, L.; Yeshurun, M.; et al. Treatment of severe steroid resistant acute GVHD with mesenchymal stromal cells (MSC). Am. J. Blood Res. 2013, 3, 225-238.

20. Griffin, M.D.; Ryan, A.E.; Alagesan, S.; Lohan, P.; Treacy, O.; Ritter, T. Anti-donor immune responses elicited by allogeneic mesenchymal stem cells: What have we learned so far? Immunol. Cell Biol. 2013, 91, 40-51.

21. Krampera, M.; Cosmi, L.; Angeli, R.; Pasini, A.; Liotta, F.; Andreini, A.; Santarlasci, V.; Mazzinghi, B.; Pizzolo, G.; Vinante, F.; et al. Role for interferon-gamma in the immunomodulatory activity of human bone marrow mesenchymal stem cells. Stem Cells Dayt. Ohio 2006, 24, 386-398.

22. Spaggiari, G.M.; Capobianco, A.; Abdelrazik, H.; Becchetti, F.; Mingari, M.C.; Moretta, L. Mesenchymal stem cells inhibit natural killer-cell proliferation, cytotoxicity, and cytokine production: Role of indoleamine 2,3-dioxygenase and prostaglandin E2. Blood 2008, 111, $1327-1333$. 
23. Klyushnenkova, E.; Mosca, J.D.; Zernetkina, V.; Majumdar, M.K.; Beggs, K.J.; Simonetti, D.W.; Deans, R.J.; McIntosh, K.R. T cell responses to allogeneic human mesenchymal stem cells: Immunogenicity, tolerance, and suppression. J. Biomed. Sci. 2005, 12, 47-57.

24. Ji, J.F.; He, B.P.; Dheen, S.T.; Tay, S.S.W. Interactions of chemokines and chemokine receptors mediate the migration of mesenchymal stem cells to the impaired site in the brain after hypoglossal nerve injury. Stem Cells Dayt. Ohio 2004, 22, 415-427.

25. Ponte, A.L.; Marais, E.; Gallay, N.; Langonné, A.; Delorme, B.; Hérault, O.; Charbord, P.; Domenech, J. The in vitro migration capacity of human bone marrow mesenchymal stem cells: Comparison of chemokine and growth factor chemotactic activities. Stem Cells Dayt. Ohio 2007, 25, 1737-1745.

26. Bajetto, A.; Bonavia, R.; Barbero, S.; Piccioli, P.; Costa, A.; Florio, T.; Schettini, G. Glial and neuronal cells express functional chemokine receptor CXCR4 and its natural ligand stromal cell-derived factor 1. J. Neurochem. 1999, 73, 2348-2357.

27. Hill, W.D.; Hess, D.C.; Martin-Studdard, A.; Carothers, J.J.; Zheng, J.; Hale, D.; Maeda, M.; Fagan, S.C.; Carroll, J.E.; Conway, S.J. SDF-1 (CXCL12) is upregulated in the ischemic penumbra following stroke: Association with bone marrow cell homing to injury. J. Neuropathol. Exp. Neurol. 2004, 63, 84-96.

28. Liu, N.; Patzak, A.; Zhang, J. CXCR4-overexpressing bone marrow-derived mesenchymal stem cells improve repair of acute kidney injury. Am. J. Physiol. Ren. Physiol. 2013, 305, F1064-F1073.

29. Cheng, Z.; Ou, L.; Zhou, X.; Li, F.; Jia, X.; Zhang, Y.; Liu, X.; Li, Y.; Ward, C.A.; Melo, L.G.; et al. Targeted migration of mesenchymal stem cells modified with CXCR4 gene to infarcted myocardium improves cardiac performance. Mol. Ther. J. Am. Soc. Gene Ther. 2008, 16, 571-579.

30. Park, S.A.; Ryu, C.H.; Kim, S.M.; Lim, J.Y.; Park, S.I.; Jeong, C.H.; Jun, J.A.; Oh, J.H.; Park, S.H.; Oh, W.; et al. CXCR4-transfected human umbilical cord blood-derived mesenchymal stem cells exhibit enhanced migratory capacity toward gliomas. Int. J. Oncol. 2011, 38, 97-103.

31. Yu, X.; Chen, D.; Zhang, Y.; Wu, X.; Huang, Z.; Zhou, H.; Zhang, Y.; Zhang, Z. Overexpression of CXCR4 in mesenchymal stem cells promotes migration, neuroprotection and angiogenesis in a rat model of stroke. J. Neurol. Sci. 2012, 316, 141-149.

32. Haque, N.; Rahman, M.T.; Abu Kasim, N.H.; Alabsi, A.M. Hypoxic culture conditions as a solution for mesenchymal stem cell based regenerative therapy. Sci. World J. 2013, doi:10.1155/2013/632972.

33. Wei, L.; Fraser, J.L.; Lu, Z.-Y.; Hu, X.; Yu, S.P. Transplantation of hypoxia preconditioned bone marrow mesenchymal stem cells enhances angiogenesis and neurogenesis after cerebral ischemia in rats. Neurobiol. Dis. 2012, 46, 635-645.

34. Wei, N.; Yu, S.P.; Gu, X.; Taylor, T.M.; Song, D.; Liu, X.-F.; Wei, L. Delayed intranasal delivery of hypoxic-preconditioned bone marrow mesenchymal stem cells enhanced cell homing and therapeutic benefits after ischemic stroke in mice. Cell Transplant. 2013, 22, 977-991.

35. Vertelov, G.; Kharazi, L.; Muralidhar, M.G.; Sanati, G.; Tankovich, T.; Kharazi, A. High targeted migration of human mesenchymal stem cells grown in hypoxia is associated with enhanced activation of RhoA. Stem Cell Res. Ther. 2013, doi:10.1186/scrt153.

36. Rombouts, W.J.C.; Ploemacher, R.E. Primary murine MSC show highly efficient homing to the bone marrow but lose homing ability following culture. Leukemia 2003, 17, 160-170. 
37. De Becker, A.; van Hummelen, P.; Bakkus, M.; vande Broek, I.; de Wever, J.; de Waele, M.; van Riet, I. Migration of culture-expanded human mesenchymal stem cells through bone marrow endothelium is regulated by matrix metalloproteinase- 2 and tissue inhibitor of metalloproteinase- 3 . Haematologica 2007, 92, 440-449.

38. Kang, S.K.; Shin, I.S.; Ko, M.S.; Jo, J.Y.; Ra, J.C. Journey of mesenchymal stem cells for homing: Strategies to enhance efficacy and safety of stem cell therapy. Stem Cells Int. 2012, doi: $10.1155 / 2012 / 342968$.

39. Deak, E.; Seifried, E.; Henschler, R. Homing pathways of mesenchymal stromal cells (MSCs) and their role in clinical applications. Int. Rev. Immunol. 2010, 29, 514-529.

40. Yukawa, H.; Watanabe, M.; Kaji, N.; Okamoto, Y.; Tokeshi, M.; Miyamoto, Y.; Noguchi, H.; Baba, Y.; Hayashi, S. Monitoring transplanted adipose tissue-derived stem cells combined with heparin in the liver by fluorescence imaging using quantum dots. Biomaterials 2012, 33, 2177-2186.

41. Walczak, P.; Zhang, J.; Gilad, A.A.; Kedziorek, D.A.; Ruiz-Cabello, J.; Young, R.G.; Pittenger, M.F.; van Zijl, P.C.M.; Huang, J.; Bulte, J.W.M. Dual-modality monitoring of targeted intraarterial delivery of mesenchymal stem cells after transient ischemia. Stroke J. Cereb. Circ. 2008, 39, 1569-1574.

42. Liu, L.; Eckert, M.A.; Riazifar, H.; Kang, D.-K.; Agalliu, D.; Zhao, W. From blood to the brain: Can systemically transplanted mesenchymal stem cells cross the blood-brain barrier? Stem Cells Int. 2013, doi:10.1155/2013/435093.

43. Steiner, B.; Roch, M.; Holtkamp, N.; Kurtz, A. Systemically administered human bone marrow-derived mesenchymal stem home into peripheral organs but do not induce neuroprotective effects in the MCAo-mouse model for cerebral ischemia. Neurosci. Lett. 2012, 513, 25-30.

44. Gutierrez-Fernandez, M.; Rodriguez-Frutos, B.; Ramos-Cejudo, J.; Teresa Vallejo-Cremades, M.; Fuentes, B.; Cerdan, S.; Diez-Tejedor, E. Effects of intravenous administration of allogenic bone marrow- and adipose tissue-derived mesenchymal stem cells on functional recovery and brain repair markers in experimental ischemic stroke. Stem Cell Res. Ther. 2013, doi:10.1186/scrt159.

45. Kean, T.J.; Lin, P.; Caplan, A.I.; Dennis, J.E. MSCs: Delivery routes and engraftment, cell-targeting strategies, and immune modulation. Stem Cells Int. 2013, doi:10.1155/2013/732742.

46. Kim, S.; Chang, K.-A.; Kim, J.A; Park, H.-G.; Ra, J.C.; Kim, H.-S.; Suh, Y.-H. The preventive and therapeutic effects of intravenous human adipose-derived stem cells in Alzheimer's disease mice. PLoS One 2012, 7, e45757.

47. Barbosa da Fonseca, L.M.; Gutfilen, B.; Rosado de Castro, P.H.; Battistella, V.; Goldenberg, R.C.S.; Kasai-Brunswick, T.; Chagas, C.L.R.; Wajnberg, E.; Maiolino, A.; Salles Xavier, S.; et al. Migration and homing of bone-marrow mononuclear cells in chronic ischemic stroke after intra-arterial injection. Exp. Neurol. 2010, 221, 122-128.

48. Lu, D.; Mahmood, A.; Wang, L.; Li, Y.; Lu, M.; Chopp, M. Adult bone marrow stromal cells administered intravenously to rats after traumatic brain injury migrate into brain and improve neurological outcome. Neuroreport 2001, 12, 559-563.

49. Zlokovic, B.V. The blood-brain barrier in health and chronic neurodegenerative disorders. Neuron 2008, 57, 178-201.

50. Baraniak, P.R.; McDevitt, T.C. Stem cell paracrine actions and tissue regeneration. Regen. Med. 2010, 5, 121-143. 
51. Parr, A.M.; Tator, C.H.; Keating, A. Bone marrow-derived mesenchymal stromal cells for the repair of central nervous system injury. Bone Marrow Transplant. 2007, 40, 609-619.

52. Chen, X.; Li, Y.; Wang, L.; Katakowski, M.; Zhang, L.; Chen, J.; Xu, Y.; Gautam, S.C.; Chopp, M. Ischemic rat brain extracts induce human marrow stromal cell growth factor production. Neuropathol. Off. J. Jpn. Soc. Neuropathol. 2002, 22, 275-279.

53. Crigler, L.; Robey, R.C.; Asawachaicharn, A.; Gaupp, D.; Phinney, D.G. Human mesenchymal stem cell subpopulations express a variety of neuro-regulatory molecules and promote neuronal cell survival and neuritogenesis. Exp. Neurol. 2006, 198, 54-64.

54. Cantinieaux, D.; Quertainmont, R.; Blacher, S.; Rossi, L.; Wanet, T.; Noël, A.; Brook, G.; Schoenen, J.; Franzen, R. Conditioned medium from bone marrow-derived mesenchymal stem cells improves recovery after spinal cord injury in rats: An original strategy to avoid cell transplantation. PLoS One 2013, 8, e69515.

55. Timmers, L.; Lim, S.K.; Arslan, F.; Armstrong, J.S.; Hoefer, I.E.; Doevendans, P.A.; Piek, J.J.; El Oakley, R.M.; Choo, A.; Lee, C.N.; et al. Reduction of myocardial infarct size by human mesenchymal stem cell conditioned medium. Stem Cell Res. 2007, 1, 129-137.

56. Timmers, L.; Lim, S.K.; Hoefer, I.E.; Arslan, F.; Lai, R.C.; van Oorschot, A.A.M.; Goumans, M.J.; Strijder, C.; Sze, S.K.; Choo, A.; et al. Human mesenchymal stem cell-conditioned medium improves cardiac function following myocardial infarction. Stem Cell Res. 2011, 6, 206-214.

57. Marcus, M.E.; Leonard, J.N. FedExosomes: Engineering therapeutic biological nanoparticles that truly deliver. Pharm. Basel Switz. 2013, 6, 659-680.

58. Johnstone, R.M.; Adam, M.; Hammond, J.R.; Orr, L.; Turbide, C. Vesicle formation during reticulocyte maturation. Association of plasma membrane activities with released vesicles (exosomes). J. Biol. Chem. 1987, 262, 9412-9420.

59. Raposo, G.; Stoorvogel, W. Extracellular vesicles: Exosomes, microvesicles, and friends. J. Cell Biol. 2013, 200, 373-383.

60. Waldenström, A.; Gennebäck, N.; Hellman, U.; Ronquist, G. Cardiomyocyte microvesicles contain DNA/RNA and convey biological messages to target cells. PLoS One 2012, 7, e34653.

61. Février, B.; Raposo, G. Exosomes: Endosomal-derived vesicles shipping extracellular messages. Curr. Opin. Cell Biol. 2004, 16, 415-421.

62. Lopez-Verrilli, M.A.; Court, F.A. Exosomes: Mediators of communication in eukaryotes. Biol. Res. 2013, 46, 5-11.

63. Biancone, L.; Bruno, S.; Deregibus, M.C.; Tetta, C.; Camussi, G. Therapeutic potential of mesenchymal stem cell-derived microvesicles. Nephrol. Dial. Transplant. 2012, 27, 3037-3042.

64. Delcayre, A.; Estelles, A.; Sperinde, J.; Roulon, T.; Paz, P.; Aguilar, B.; Villanueva, J.; Khine, S.; le Pecq, J.-B. Exosome Display technology: Applications to the development of new diagnostics and therapeutics. Blood Cells Mol. Dis. 2005, 35, 158-168.

65. Zeelenberg, I.S.; Ostrowski, M.; Krumeich, S.; Bobrie, A.; Jancic, C.; Boissonnas, A.; Delcayre, A.; le Pecq, J.-B.; Combadière, B.; Amigorena, S.; et al. Targeting tumor antigens to secreted membrane vesicles in vivo induces efficient antitumor immune responses. Cancer Res. 2008, 68, 1228-1235.

66. Alvarez-Erviti, L.; Seow, Y.; Yin, H.; Betts, C.; Lakhal, S.; Wood, M.J.A. Delivery of siRNA to the mouse brain by systemic injection of targeted exosomes. Nat. Biotechnol. 2011, 29, $341-345$. 
67. Mizrak, A.; Bolukbasi, M.F.; Ozdener, G.B.; Brenner, G.J.; Madlener, S.; Erkan, E.P.; Ströbel, T.; Breakefield, X.O.; Saydam, O. Genetically engineered microvesicles carrying suicide mRNA/protein inhibit schwannoma tumor growth. Mol. Ther. J. Am. Soc. Gene Ther. 2013, 21, 101-108.

68. Bolukbasi, M.F.; Mizrak, A.; Ozdener, G.B.; Madlener, S.; Ströbel, T.; Erkan, E.P.; Fan, J.-B.; Breakefield, X.O.; Saydam, O. miR-1289 and "Zipcode"-like Sequence Enrich mRNAs in Microvesicles. Mol. Ther. Nucleic Acids 2012, doi:10.1038/mtna.2011.2.

69. Xin, H.; Li, Y.; Buller, B.; Katakowski, M.; Zhang, Y.; Wang, X.; Shang, X.; Zhang, Z.G.; Chopp, M. Exosome-mediated transfer of miR-133b from multipotent mesenchymal stromal cells to neural cells contributes to neurite outgrowth. Stem Cells Dayt. Ohio 2012, 30, 1556-1564.

70. Karshieva, S.S.; Krasikov, L.S.; Beliavskǐl, A.V. [Mesenchymal stem cells as an antitumor therapy tool] (in Russian). Mol. Biol. 2013, 47, 50-60.

71. Aiuti, A.; Slavin, S.; Aker, M.; Ficara, F.; Deola, S.; Mortellaro, A.; Morecki, S.; Andolfi, G.; Tabucchi, A.; Carlucci, F.; et al. Correction of ADA-SCID by stem cell gene therapy combined with nonmyeloablative conditioning. Science 2002, 296, 2410-2413.

72. Cockrell, A.S.; Kafri, T. Gene delivery by lentivirus vectors. Mol. Biotechnol. 2007, 36, 184-204.

73. Hacein-Bey-Abina, S.; Garrigue, A.; Wang, G.P.; Soulier, J.; Lim, A.; Morillon, E.; Clappier, E.; Caccavelli, L.; Delabesse, E.; Beldjord, K.; et al. Insertional oncogenesis in 4 patients after retrovirus-mediated gene therapy of SCID-X1. J. Clin. Investig. 2008, 118, 3132-3142.

74. Lewis, P.; Hensel, M.; Emerman, M. Human immunodeficiency virus infection of cells arrested in the cell cycle. EMBO J. 1992, 11, 3053-3058.

75. Cartier, N.; Hacein-Bey-Abina, S.; Bartholomae, C.C.; Veres, G.; Schmidt, M.; Kutschera, I.; Vidaud, M.; Abel, U.; Dal-Cortivo, L.; Caccavelli, L.; et al. Hematopoietic stem cell gene therapy with a lentiviral vector in X-linked adrenoleukodystrophy. Science 2009, 326, 818-823.

76. Liechtenstein, T.; Perez-Janices, N.; Escors, D. Lentiviral vectors for cancer immunotherapy and clinical applications. Cancers 2013, 5, 815-837.

77. Bokhoven, M.; Stephen, S.L.; Knight, S.; Gevers, E.F.; Robinson, I.C.; Takeuchi, Y.; Collins, M.K. Insertional gene activation by lentiviral and gammaretroviral vectors. J. Virol. 2009, 83, 283-294.

78. Raper, S.E.; Chirmule, N.; Lee, F.S.; Wivel, N.A.; Bagg, A.; Gao, G.; Wilson, J.M.; Batshaw, M.L. Fatal systemic inflammatory response syndrome in a ornithine transcarbamylase deficient patient following adenoviral gene transfer. Mol. Genet. Metab. 2003, 80, 148-158.

79. Ylä-Herttuala, S. Endgame: Glybera finally recommended for approval as the first gene therapy drug in the European union. Mol. Ther. J. Am. Soc. Gene Ther. 2012, 20, 1831-1832.

80. Mingozzi, F.; High, K.A. Immune responses to AAV vectors: Overcoming barriers to successful gene therapy. Blood 2013, 122, 23-36.

81. Stephen, S.L.; Sivanandam, V.G.; Kochanek, S. Homologous and heterologous recombination between adenovirus vector DNA and chromosomal DNA. J. Gene Med. 2008, 10, 1176-1189.

82. Nakamizo, A.; Marini, F.; Amano, T.; Khan, A.; Studeny, M.; Gumin, J.; Chen, J.; Hentschel, S.; Vecil, G.; Dembinski, J.; et al. Human bone marrow-derived mesenchymal stem cells in the treatment of gliomas. Cancer Res. 2005, 65, 3307-3318.

83. Jiang, H.; Gomez-Manzano, C.; Lang, F.F.; Alemany, R.; Fueyo, J. Oncolytic adenovirus: Preclinical and clinical studies in patients with human malignant gliomas. Curr. Gene Ther. 2009, 9, 422-427. 
84. Hai, C.; Jin, Y.-M.; Jin, W.-B.; Han, Z.-Z.; Cui, M.-N.; Piao, X.-Z.; Shen, X.-H.; Zhang, S.-N.; Sun, H.-H. Application of mesenchymal stem cells as a vehicle to deliver replication-competent adenovirus for treating malignant glioma. Chin. J. Cancer 2012, 31, 233-240.

85. Helledie, T.; Nurcombe, V.; Cool, S.M. A simple and reliable electroporation method for human bone marrow mesenchymal stem cells. Stem Cells Dev. 2008, 17, 837-848.

86. Madeira, C.; Mendes, R.D.; Ribeiro, S.C.; Boura, J.S.; Aires-Barros, M.R.; da Silva, C.L.; Cabral, J.M.S. Nonviral gene delivery to mesenchymal stem cells using cationic liposomes for gene and cell therapy. J. Biomed. Biotechnol. 2010, doi:10.1155/2010/735349.

87. Dwivedi, P.P.; Anderson, P.J.; Powell, B.C. Development of an efficient, non-viral transfection method for studying gene function and bone growth in human primary cranial suture mesenchymal cells reveals that the cells respond to BMP2 and BMP3. BMC Biotechnol. 2012, doi:10.1186/1472-6750-12-45.

88. Cao, X.; Deng, W.; Wei, Y.; Su, W.; Yang, Y.; Wei, Y.; Yu, J.; Xu, X. Encapsulation of plasmid DNA in calcium phosphate nanoparticles: Stem cell uptake and gene transfer efficiency. Int. J. Nanomed. 2011, 6, 3335-3349.

89. Han, S.-W.; Nakamura, C.; Kotobuki, N.; Obataya, I.; Ohgushi, H.; Nagamune, T.; Miyake, J. High-efficiency DNA injection into a single human mesenchymal stem cell using a nanoneedle and atomic force microscopy. Nanomed. Nanotechnol. Biol. Med. 2008, 4, 215-225.

90. Deng, W.-W.; Cao, X.; Wang, M.; Yang, Y.; Su, W.-Y.; Wei, Y.-W.; Ou-Yang, Z.; Yu, J.-N.; $\mathrm{Xu}, \mathrm{X} . \mathrm{-M}$. Efficient gene delivery to mesenchymal stem cells by an ethylenediamine-modified polysaccharide from mulberry leaves. Small Weinh. Bergstr. Ger. 2012, 8, 441-451.

91. Deng, W.; Fu, M.; Cao, Y.; Cao, X.; Wang, M.; Yang, Y.; Qu, R.; Li, J.; Xu, X.; Yu, J. Angelica sinensis polysaccharide nanoparticles as novel non-viral carriers for gene delivery to mesenchymal stem cells. Nanomed. Nanotechnol. Biol. Med. 2013, 9, 1181-1191.

92. Peng, L.-H.; Tsang, S.-Y.; Tabata, Y.; Gao, J.-Q. Genetically-manipulated adult stem cells as therapeutic agents and gene delivery vehicle for wound repair and regeneration. J. Controlled Release 2012, 157, 321-330.

93. Jo, J.-I.; Nagaya, N.; Miyahara, Y.; Kataoka, M.; Harada-Shiba, M.; Kangawa, K.; Tabata, Y. Transplantation of genetically engineered mesenchymal stem cells improves cardiac function in rats with myocardial infarction: Benefit of a novel nonviral vector, cationized dextran. Tissue Eng. 2007, 13, 313-322.

94. Boura, J.S.; Santos, F.D.; Gimble, J.M.; Cardoso, C.M.P.; Madeira, C.; Cabral, J.M.S.; da Silva, C.L. Direct head-to-head comparison of cationic liposome-mediated gene delivery to mesenchymal stem/stromal cells of different human sources: A comprehensive study. Hum. Gene Ther. Methods 2013, 24, 38-48.

95. Palpant, N.J.; Dudzinski, D. Zinc finger nucleases: Looking toward translation. Gene Ther. 2013, 20, 121-127.

96. Joung, J.K.; Sander, J.D. TALENs: A widely applicable technology for targeted genome editing. Nat. Rev. Mol. Cell Biol. 2013, 14, 49-55.

97. Cong, L.; Ran, F.A.; Cox, D.; Lin, S.; Barretto, R.; Habib, N.; Hsu, P.D.; Wu, X.; Jiang, W.; Marraffini, L.A.; et al. Multiplex genome engineering using CRISPR/Cas systems. Science 2013, 339, 819-823. 
98. Gaj, T.; Gersbach, C.A.; Barbas, C.F., 3rd. ZFN, TALEN, and CRISPR/Cas-based methods for genome engineering. Trends Biotechnol. 2013, 31, 397-405.

99. Benabdallah, B.F.; Allard, E.; Yao, S.; Friedman, G.; Gregory, P.D.; Eliopoulos, N.; Fradette, J.; Spees, J.L.; Haddad, E.; Holmes, M.C.; et al. Targeted gene addition to human mesenchymal stromal cells as a cell-based plasma-soluble protein delivery platform. Cytotherapy 2010, 12, 394-399.

100. Kouprina, N.; Earnshaw, W.C.; Masumoto, H.; Larionov, V. A new generation of human artificial chromosomes for functional genomics and gene therapy. Cell. Mol. Life Sci. 2013, 70, 1135-1148.

101. Hoshiya, H.; Kazuki, Y.; Abe, S.; Takiguchi, M.; Kajitani, N.; Watanabe, Y.; Yoshino, T.; Shirayoshi, Y.; Higaki, K.; Messina, G.; et al. A highly stable and nonintegrated human artificial chromosome (HAC) containing the $2.4 \mathrm{Mb}$ entire human dystrophin gene. Mol. Ther. J. Am. Soc. Gene Ther. 2009, 17, 309-317.

102. Kurosaki, H.; Hiratsuka, M.; Imaoka, N.; Iida, Y.; Uno, N.; Kazuki, Y.; Ishihara, C.; Yakura, Y.; Mimuro, J.; Sakata, Y.; et al. Integration-free and stable expression of FVIII using a human artificial chromosome. J. Hum. Genet. 2011, 56, 727-733.

103. Ren, X.; Katoh, M.; Hoshiya, H.; Kurimasa, A.; Inoue, T.; Ayabe, F.; Shibata, K.; Toguchida, J.; Oshimura, M. A novel human artificial chromosome vector provides effective cell lineage-specific transgene expression in human mesenchymal stem cells. Stem Cells Dayt. Ohio 2005, 23, 1608-1616.

104. Kinoshita, Y.; Kamitani, H.; Mamun, M.H.; Wasita, B.; Kazuki, Y.; Hiratsuka, M.; Oshimura, M.; Watanabe, T. A gene delivery system with a human artificial chromosome vector based on migration of mesenchymal stem cells towards human glioblastoma HTB14 cells. Neurol. Res. 2010, 32, 429-437.

105. Wirth, T.; Parker, N.; Ylä-Herttuala, S. History of gene therapy. Gene 2013, 525, 162-169.

106. Szybalski, W. The 50th anniversary of gene therapy: Beginnings and present realities. Gene 2013, 525, 151-154.

107. Calne, D.B.; Snow, B.J.; Lee, C. Criteria for diagnosing Parkinson's disease. Ann. Neurol. 1992, 32, S125-S127.

108. Klein, C.; Westenberger, A. Genetics of Parkinson's disease. Cold Spring Harb. Perspect. Med. 2012, doi:10.1101/cshperspect.a008888.

109. Fearnley, J.M.; Lees, A.J. Ageing and Parkinson's disease: Substantia nigra regional selectivity. Brain J. Neurol. 1991, 114, 2283-2301.

110. Dexter, D.T.; Jenner, P. Parkinson disease: From pathology to molecular disease mechanisms. Free Radic. Biol. Med. 2013, 62, 132-144.

111. Baba, M.; Nakajo, S.; Tu, P.H.; Tomita, T.; Nakaya, K.; Lee, V.M.; Trojanowski, J.Q.; Iwatsubo, T. Aggregation of alpha-synuclein in Lewy bodies of sporadic Parkinson's disease and dementia with Lewy bodies. Am. J. Pathol. 1998, 152, 879-884.

112. Bargiotas, P.; Konitsiotis, S. Levodopa-induced dyskinesias in Parkinson's disease: Emerging treatments. Neuropsychiatr. Dis. Treat. 2013, 9, 1605-1617.

113. Walter, B.L.; Vitek, J.L. Surgical treatment for Parkinson's disease. Lancet Neurol. 2004, 3, 719-728. 
114. Allen, P.J.; Feigin, A. Gene-based therapies in Parkinson's disease. Neurother. J. Am. Soc. Exp. Neurother. 2013, doi:10.1007/s13311-013-0233-2.

115. Lin, L.F.; Doherty, D.H.; Lile, J.D.; Bektesh, S.; Collins, F. GDNF: A glial cell line-derived neurotrophic factor for midbrain dopaminergic neurons. Science 1993, 260, 1130-1132.

116. Pascual, A.; Hidalgo-Figueroa, M.; Gómez-Díaz, R.; López-Barneo, J. GDNF and protection of adult central catecholaminergic neurons. J. Mol. Endocrinol. 2011, 46, R83-R92.

117. Durbec, P.; Marcos-Gutierrez, C.V.; Kilkenny, C.; Grigoriou, M.; Wartiowaara, K.; Suvanto, P.; Smith, D.; Ponder, B.; Costantini, F.; Saarma, M. GDNF signalling through the Ret receptor tyrosine kinase. Nature 1996, 381, 789-793.

118. Airaksinen, M.S.; Holm, L.; Hätinen, T. Evolution of the GDNF family ligands and receptors. Brain Behav. Evol. 2006, 68, 181-190.

119. Worby, C.A.; Vega, Q.C.; Zhao, Y.; Chao, H.H.; Seasholtz, A.F.; Dixon, J.E. Glial cell line-derived neurotrophic factor signals through the RET receptor and activates mitogen-activated protein kinase. J. Biol. Chem. 1996, 271, 23619-23622.

120. Burke, R.E. Intracellular signalling pathways in dopamine cell death and axonal degeneration. Prog. Brain Res. 2010, 183, 79-97.

121. Gunjima, K.; Tomiyama, R.; Takakura, K.; Yamada, T.; Hashida, K.; Nakamura, Y.; Konishi, T.; Matsugo, S.; Hori, O. 3,4-Dihydroxybenzalacetone protects against Parkinson's disease-related neurotoxin 6-OHDA through Akt/Nrf2/glutathione pathway. J. Cell. Biochem. 2014, 115, 151-160.

122. Hidalgo-Figueroa, M.; Bonilla, S.; Gutiérrez, F.; Pascual, A.; López-Barneo, J. GDNF is predominantly expressed in the $\mathrm{PV}+$ neostriatal interneuronal ensemble in normal mouse and after injury of the nigrostriatal pathway. J. Neurosci. 2012, 32, 864-872.

123. Nutt, J.G.; Burchiel, K.J.; Comella, C.L.; Jankovic, J.; Lang, A.E.; Laws, E.R., Jr.; Lozano, A.M.; Penn, R.D.; Simpson, R.K., Jr.; Stacy, M.; et al. Implanted intracerebroventricular. Glial cell line-derived neurotrophic factor Randomized, double-blind trial of glial cell line-derived neurotrophic factor (GDNF) in PD. Neurology 2003, 60, 69-73.

124. Gill, S.S.; Patel, N.K.; Hotton, G.R.; O’Sullivan, K.; McCarter, R.; Bunnage, M.; Brooks, D.J.; Svendsen, C.N.; Heywood, P. Direct brain infusion of glial cell line-derived neurotrophic factor in Parkinson disease. Nat. Med. 2003, 9, 589-595.

125. Slevin, J.T.; Gerhardt, G.A.; Smith, C.D.; Gash, D.M.; Kryscio, R.; Young, B. Improvement of bilateral motor functions in patients with Parkinson disease through the unilateral intraputaminal infusion of glial cell line-derived neurotrophic factor. J. Neurosurg. 2005, 102, 216-222.

126. Lang, A.E.; Gill, S.; Patel, N.K.; Lozano, A.; Nutt, J.G.; Penn, R.; Brooks, D.J.; Hotton, G.; Moro, E.; Heywood, P.; et al. Randomized controlled trial of intraputamenal glial cell line-derived neurotrophic factor infusion in Parkinson disease. Ann. Neurol. 2006, 59, 459-466.

127. Kordower, J.H.; Palfi, S.; Chen, E.Y.; Ma, S.Y.; Sendera, T.; Cochran, E.J.; Cochran, E.J.; Mufson, E.J.; Penn, R.; Goetz, C.G.; et al. Clinicopathological findings following intraventricular glial-derived neurotrophic factor treatment in a patient with Parkinson's disease. Ann. Neurol. 1999, 46, 419-424.

128. Kitada, M.; Dezawa, M. Parkinson's disease and mesenchymal stem cells: Potential for cell-based therapy. Park. Dis. 2012, doi:10.1155/2012/873706. 
129. Venkataramana, N.K.; Kumar, S.K.V.; Balaraju, S.; Radhakrishnan, R.C.; Bansal, A.; Dixit, A.; Rao, D.K.; Das, M.; Jan, M.; Gupta, P.K.; et al. Open-labeled study of unilateral autologous bone-marrow-derived mesenchymal stem cell transplantation in Parkinson's disease. Transl. Res. J. Lab. Clin. Med. 2010, 155, 62-70.

130. Venkataramana, N.K.; Pal, R.; Rao, S.A. V.; Naik, A.L.; Jan, M.; Nair, R.; Sanjeev, C.C.; Kamble, R.B.; Murthy, D.P.; Chaitanya, K. Bilateral transplantation of allogenic adult human bone marrow-derived mesenchymal stem cells into the subventricular zone of Parkinson's disease: A pilot clinical study. Stem Cells Int. 2012, doi:10.1155/2012/931902.

131. Moloney, T.C.; Rooney, G.E.; Barry, F.P.; Howard, L.; Dowd, E. Potential of rat bone marrow-derived mesenchymal stem cells as vehicles for delivery of neurotrophins to the Parkinsonian rat brain. Brain Res. 2010, 1359, 33-43.

132. Glavaski-Joksimovic, A.; Virag, T.; Mangatu, T.A.; McGrogan, M.; Wang, X.S.; Bohn, M.C. Glial cell line-derived neurotrophic factor-secreting genetically modified human bone marrow-derived mesenchymal stem cells promote recovery in a rat model of Parkinson's disease. J. Neurosci. Res. 2010, 88, 2669-2681.

133. Sadan, O.; Bahat-Stromza, M.; Barhum, Y.; Levy, Y.S.; Pisnevsky, A.; Peretz, H.; Ilan, A.B.; Bulvik, S.; Shemesh, N.; Krepel, D.; et al. Protective effects of neurotrophic factor-secreting cells in a 6-OHDA rat model of Parkinson disease. Stem Cells Dev. 2009, 18, 1179-1190.

134. Wu, J.; Yu, W.; Chen, Y.; Su, Y.; Ding, Z.; Ren, H.; Jiang, Y.; Wang, J. Intrastriatal transplantation of GDNF-engineered BMSCs and its neuroprotection in lactacystin-induced Parkinsonian rat model. Neurochem. Res. 2010, 35, 495-502.

135. Ren, Z.; Wang, J.; Wang, S.; Zou, C.; Li, X.; Guan, Y.; Chen, Z.; Zhang, Y.A. Autologous transplantation of GDNF-expressing mesenchymal stem cells protects against MPTP-induced damage in cynomolgus monkeys. Sci. Rep. 2013, doi:10.1038/srep02786.

136. Lee, J.K.; Jin, H.K.; Bae, J.-S. Bone marrow-derived mesenchymal stem cells reduce brain amyloid-beta deposition and accelerate the activation of microglia in an acutely induced Alzheimer's disease mouse model. Neurosci. Lett. 2009, 450, 136-141.

137. Lee, H.J.; Lee, J.K.; Lee, H.; Carter, J.E.; Chang, J.W.; Oh, W.; Yang, Y.S.; Suh, J.-G.; Lee, B.-H.; Jin, H.K.; et al. Human umbilical cord blood-derived mesenchymal stem cells improve neuropathology and cognitive impairment in an Alzheimer's disease mouse model through modulation of neuroinflammation. Neurobiol. Aging 2012, 33, 588-602.

138. Wu, Q.-Y.; Li, J.; Feng, Z.-T.; Wang, T.-H. Bone marrow stromal cells of transgenic mice can improve the cognitive ability of an Alzheimer's disease rat model. Neurosci. Lett. 2007, 417, 281-285.

139. Li, L.-Y.; Li, J.-T.; Wu, Q.-Y.; Li, J.; Feng, Z.-T.; Liu, S.; Wang, T.-H. Transplantation of NGF-gene-modified bone marrow stromal cells into a rat model of Alzheimer' disease. J. Mol. Neurosci. 2008, 34, 157-163.

140. Dey, N.D.; Bombard, M.C.; Roland, B.P.; Davidson, S.; Lu, M.; Rossignol, J.; Sandstrom, M.I.; Skeel, R.L.; Lescaudron, L.; Dunbar, G.L. Genetically engineered mesenchymal stem cells reduce behavioral deficits in the YAC 128 mouse model of Huntington's disease. Behav. Brain Res. 2010, 214, 193-200. 
141. Mega, M.S.; Cummings, J.L.; Fiorello, T.; Gornbein, J. The spectrum of behavioral changes in Alzheimer's disease. Neurology 1996, 46, 130-135.

142. Prince, M.; Bryce, R.; Albanese, E.; Wimo, A.; Ribeiro, W.; Ferri, C.P. The global prevalence of dementia: A systematic review and metaanalysis. Alzheimers Dement. J. Alzheimers Assoc. 2013, 9, 63-75.

143. Rocca, W.A.; Petersen, R.C.; Knopman, D.S.; Hebert, L.E.; Evans, D.A.; Hall, K.S.; Gao, S.; Unverzagt, F.W.; Langa, K.M.; Larson, E.B.; et al. Trends in the incidence and prevalence of Alzheimer's disease, dementia, and cognitive impairment in the United States. Alzheimers Dement. J. Alzheimers Assoc. 2011, 7, 80-93.

144. Alzheimer's Association 2012. Alzheimer's disease facts and figures. Alzheimers Dement. J. Alzheimers Assoc. 2012, 8, 131-168.

145. Ballard, C.; Gauthier, S.; Corbett, A.; Brayne, C.; Aarsland, D.; Jones, E. Alzheimer's disease. Lancet 2011, 377, 1019-1031.

146. Bettens, K.; Sleegers, K.; van Broeckhoven, C. Genetic insights in Alzheimer's disease. Lancet Neurol. 2013, 12, 92-104.

147. Corder, E.H.; Saunders, A.M.; Strittmatter, W.J.; Schmechel, D.E.; Gaskell, P.C.; Small, G.W.; Roses, A.D.; Haines, J.L.; Pericak-Vance, M.A. Gene dose of apolipoprotein E type 4 allele and the risk of Alzheimer's disease in late onset families. Science 1993, 261, 921-923.

148. Glenner, G.G.; Wong, C.W. Alzheimer's disease and Down's syndrome: Sharing of a unique cerebrovascular amyloid fibril protein. Biochem. Biophys. Res. Commun. 1984, 122, 1131-1135.

149. Grundke-Iqbal, I.; Iqbal, K.; Quinlan, M.; Tung, Y.C.; Zaidi, M.S.; Wisniewski, H.M. Microtubule-associated protein tau. A component of Alzheimer paired helical filaments. J. Biol. Chem. 1986, 261, 6084-6089.

150. Serrano-Pozo, A.; Frosch, M.P.; Masliah, E.; Hyman, B.T. Neuropathological alterations in Alzheimer disease. Cold Spring Harb. Perspect. Med. 2011, doi:10.1101/cshperspect.a00618.

151. Francis, P.T.; Palmer, A.M.; Snape, M.; Wilcock, G.K. The cholinergic hypothesis of Alzheimer's disease: A review of progress. J. Neurol. Neurosurg. Psychiatry 1999, 66, 137-147.

152. Aisen, P.S.; Cummings, J.; Schneider, L.S. Symptomatic and nonamyloid/tau based pharmacologic treatment for Alzheimer disease. Cold Spring Harb. Perspect. Med. 2012, doi:10.1101/cshperspect.a006395.

153. Noetzli, M.; Eap, C.B. Pharmacodynamic, pharmacokinetic and pharmacogenetic aspects of drugs used in the treatment of Alzheimer's disease. Clin. Pharmacokinet. 2013, 52, 225-241.

154. Francis, P.T.; Ramírez, M.J.; Lai, M.K. Neurochemical basis for symptomatic treatment of Alzheimer's disease. Neuropharmacology 2010, 59, 221-229.

155. Cheng, B.; Gong, H.; Xiao, H.; Petersen, R.B.; Zheng, L.; Huang, K. Inhibiting toxic aggregation of amyloidogenic proteins: A therapeutic strategy for protein misfolding diseases. Biochim. Biophys. Acta 2013, 1830, 4860-4871.

156. Schafer, K.N.; Cisek, K.; Huseby, C.J.; Chang, E.; Kuret, J. Structural determinants of tau aggregation inhibitor potency. J. Biol. Chem. 2013, 288, 32599-32611.

157. Salomone, S.; Caraci, F.; Leggio, G.M.; Fedotova, J.; Drago, F. New pharmacological strategies for treatment of Alzheimer's disease: Focus on disease modifying drugs. Br. J. Clin. Pharmacol. 2012, 73, 504-517. 
158. Lemere, C.A. Developing novel immunogens for a safe and effective Alzheimer's disease vaccine. Prog. Brain Res. 2009, 175, 83-93.

159. Mufson, E.J.; Conner, J.M.; Kordower, J.H. Nerve growth factor in Alzheimer's disease: Defective retrograde transport to nucleus basalis. Neuroreport 1995, 6, 1063-1066.

160. Frade, J.M.; Barde, Y.A. Nerve growth factor: Two receptors, multiple functions. BioEssays News Rev. Mol. Cell Dev. Biol. 1998, 20, 137-145.

161. Kaplan, D.R.; Miller, F.D. Neurotrophin signal transduction in the nervous system. Curr. Opin. Neurobiol. 2000, 10, 381-391.

162. Majdan, M.; Miller, F.D. Neuronal life and death decisions functional antagonism between the Trk and p75 neurotrophin receptors. Int. J. Dev. Neurosci. Off. J. Int. Soc. Dev. Neurosci. 1999, $17,153-161$.

163. Counts, S.E.; Nadeem, M.; Wuu, J.; Ginsberg, S.D.; Saragovi, H.U.; Mufson, E.J. Reduction of cortical TrkA but not p75(NTR) protein in early-stage Alzheimer's disease. Ann. Neurol. 2004, $56,520-531$.

164. Ginsberg, S.D.; Che, S.; Wuu, J.; Counts, S.E.; Mufson, E.J. Down regulation of trk but not $\mathrm{p} 75^{\mathrm{NTR}}$ gene expression in single cholinergic basal forebrain neurons mark the progression of Alzheimer's disease. J. Neurochem. 2006, 97, 475-487.

165. Coulson, E.J.; May, L.M.; Sykes, A.M.; Hamlin, A.S. The role of the p75 neurotrophin receptor in cholinergic dysfunction in Alzheimer's disease. Neurosci. Rev. J. Bringing Neurobiol. Neurol. Psychiatry 2009, 15, 317-323.

166. Matrone, C.; Marolda, R.; Ciafrè, S.; Ciotti, M.T.; Mercanti, D.; Calissano, P. Tyrosine kinase nerve growth factor receptor switches from prosurvival to proapoptotic activity via Abeta-mediated phosphorylation. Proc. Natl. Acad. Sci. USA 2009, 106, 11358-11363.

167. Lucidi-Phillipi, C.A.; Clary, D.O.; Reichardt, L.F.; Gage, F.H. TrkA activation is sufficient to rescue axotomized cholinergic neurons. Neuron 1996, 16, 653-663.

168. Williams, L.R.; Varon, S.; Peterson, G.M.; Wictorin, K.; Fischer, W.; Bjorklund, A.; Gage, F.H. Continuous infusion of nerve growth factor prevents basal forebrain neuronal death after fimbria fornix transection. Proc. Natl. Acad. Sci. USA 1986, 83, 9231-9235.

169. Cattaneo, A.; Calissano, P. Nerve growth factor and Alzheimer's disease: New facts for an old hypothesis. Mol. Neurobiol. 2012, 46, 588-604.

170. Aloe, L.; Rocco, M.L.; Bianchi, P.; Manni, L. Nerve growth factor: From the early discoveries to the potential clinical use. J. Transl. Med. 2012, doi:10.1186/1479-5876-10-239.

171. Saragovi, H.U.; Gehring, K. Development of pharmacological agents for targeting neurotrophins and their receptors. Trends Pharmacol. Sci. 2000, 21, 93-98.

172. Olson, L.; Nordberg, A.; von Holst, H.; Bäckman, L.; Ebendal, T.; Alafuzoff, I.; Amberla, K.; Hartvig, P.; Herlitz, A.; Lilja, A. Nerve growth factor affects 11C-nicotine binding, blood flow, EEG, and verbal episodic memory in an Alzheimer patient (case report). J. Neural Transm. Park. Dis. Dement. Sect. 1992, 4, 79-95.

173. Eriksdotter Jönhagen, M.; Nordberg, A.; Amberla, K.; Bäckman, L.; Ebendal, T.; Meyerson, B.; Olson, L.; Seiger; Shigeta, M.; Theodorsson, E.; et al. Intracerebroventricular infusion of nerve growth factor in three patients with Alzheimer's disease. Dement. Geriatr. Cogn. Disord. 1998, 9, 246-257. 
174. Nicol, G.D.; Vasko, M.R. Unraveling the story of NGF-mediated sensitization of nociceptive sensory neurons: ON or OFF the Trks? Mol. Interv. 2007, 7, 26-41.

175. Capsoni, S.; Covaceuszach, S.; Marinelli, S.; Ceci, M.; Bernardo, A.; Minghetti, L.; Ugolini, G.; Pavone, F.; Cattaneo, A. Taking pain out of NGF: A "painless" NGF mutant, linked to hereditary sensory autonomic neuropathy type V, with full neurotrophic activity. PLoS One 2011, 6, e17321.

176. Capsoni, S.; Marinelli, S.; Ceci, M.; Vignone, D.; Amato, G.; Malerba, F.; Paoletti, F.; Meli, G.; Viegi, A.; Pavone, F.; et al. Intranasal "painless" human Nerve Growth Factor [corrected] slows amyloid neurodegeneration and prevents memory deficits in App X PS1 mice. PLoS One 2012, 7, e37555.

177. Tuszynski, M.H.; Thal, L.; Pay, M.; Salmon, D.P.; U, H.S.; Bakay, R.; Patel, P.; Blesch, A.; Vahlsing, H.L.; Ho, G.; et al. A phase 1 clinical trial of nerve growth factor gene therapy for Alzheimer disease. Nat. Med. 2005, 11, 551-555.

178. Weissmiller, A.M.; Wu, C. Current advances in using neurotrophic factors to treat neurodegenerative disorders. Transl. Neurodegener. 2012, doi:10.1186/2047-9158-1-14.

179. Kim, J.-Y.; Kim, D.H.; Kim, J.H.; Lee, D.; Jeon, H.B.; Kwon, S.-J.; Kim, S.M.; Yoo, Y.J.; Lee, E.H.; Choi, S.J.; et al. Soluble intracellular adhesion molecule-1 secreted by human umbilical cord blood-derived mesenchymal stem cell reduces amyloid- $\beta$ plaques. Cell Death Differ. 2012, 19 , 680-691.

180. Katsuda, T.; Tsuchiya, R.; Kosaka, N.; Yoshioka, Y.; Takagaki, K.; Oki, K.; Takeshita, F.; Sakai, Y.; Kuroda, M.; Ochiya, T. Human adipose tissue-derived mesenchymal stem cells secrete functional neprilysin-bound exosomes. Sci. Rep. 2013, doi:10.1038/srep01197.

181. Purdon, S.E.; Mohr, E.; Ilivitsky, V.; Jones, B.D. Huntington's disease: Pathogenesis, diagnosis and treatment. J. Psychiatry Neurosci. JPN 1994, 19, 359-367.

182. Pringsheim, T.; Wiltshire, K.; Day, L.; Dykeman, J.; Steeves, T.; Jette, N. The incidence and prevalence of Huntington's disease: A systematic review and meta-analysis. Mov. Disord. Off. J. Mov. Disord. Soc. 2012, 27, 1083-1091.

183. The Huntington's Disease Collaborative Research Group. A novel gene containing a trinucleotide repeat that is expanded and unstable on Huntington's disease chromosomes. Cell 1993, 72, 971-983.

184. Reiner, A.; Albin, R.L.; Anderson, K.D.; D’Amato, C.J.; Penney, J.B.; Young, A.B. Differential loss of striatal projection neurons in Huntington disease. Proc. Natl. Acad. Sci. USA 1988, 85, 5733-5737.

185. Ranen, N.G.; Stine, O.C.; Abbott, M.H.; Sherr, M.; Codori, A.M.; Franz, M.L.; Chao, N.I.; Chung, A.S.; Pleasant, N.; Callahan, C. Anticipation and instability of IT-15 (CAG)n repeats in parent-offspring pairs with Huntington disease. Am. J. Hum. Genet. 1995, 57, 593-602.

186. Andrade, M.A.; Bork, P. HEAT repeats in the Huntington's disease protein. Nat. Genet. 1995, $11,115-116$.

187. Li, S.-H.; Li, X.-J. Huntingtin and its role in neuronal degeneration. Neurosci. Rev. J. Bringing Neurobiol. Neurol. Psychiatry 2004, 10, 467-475.

188. DiFiglia, M.; Sapp, E.; Chase, K.O.; Davies, S.W.; Bates, G.P.; Vonsattel, J.P.; Aronin, N. Aggregation of huntingtin in neuronal intranuclear inclusions and dystrophic neurites in brain. Science 1997, 277, 1990-1993. 
189. Finkbeiner, S.; Mitra, S. The ubiquitin-proteasome pathway in Huntington's disease. Sci. World J. 2008, 8, 421-433.

190. Zuccato, C.; Valenza, M.; Cattaneo, E. Molecular mechanisms and potential therapeutical targets in Huntington's disease. Physiol. Rev. 2010, 90, 905-981.

191. Zuccato, C.; Ciammola, A.; Rigamonti, D.; Leavitt, B.R.; Goffredo, D.; Conti, L.; MacDonald, M.E.; Friedlander, R.M.; Silani, V.; Hayden, M.R.; et al. Loss of huntingtin-mediated BDNF gene transcription in Huntington's disease. Science 2001, 293, 493-498.

192. Altar, C.A.; Cai, N.; Bliven, T.; Juhasz, M.; Conner, J.M.; Acheson, A.L.; Lindsay, R.M.; Wiegand, S.J. Anterograde transport of brain-derived neurotrophic factor and its role in the brain. Nature 1997, 389, 856-860.

193. Zuccato, C.; Cattaneo, E. Role of brain-derived neurotrophic factor in Huntington's disease. Prog. Neurobiol. 2007, 81, 294-330.

194. Mason, S.L.; Barker, R.A. Emerging drug therapies in Huntington's disease. Expert Opin. Emerg. Drugs 2009, 14, 273-297.

195. Adam, O.R.; Jankovic, J. Symptomatic treatment of Huntington disease. Neurother. J. Am. Soc. Exp. Neurother. 2008, 5, 181-197.

196. Pettibone, D.J.; Totaro, J.A.; Pflueger, A.B. Tetrabenazine-induced depletion of brain monoamines: Characterization and interaction with selected antidepressants. Eur. J. Pharmacol. 1984, 102, 425-430.

197. DiFiglia, M.; Sena-Esteves, M.; Chase, K.; Sapp, E.; Pfister, E.; Sass, M.; Yoder, J.; Reeves, P.; Pandey, R.K.; Rajeev, K.G.; et al. Therapeutic silencing of mutant huntingtin with siRNA attenuates striatal and cortical neuropathology and behavioral deficits. Proc. Natl. Acad. Sci. USA 2007, 104, 17204-17209.

198. Drouet, V.; Perrin, V.; Hassig, R.; Dufour, N.; Auregan, G.; Alves, S.; Bonvento, G.; Brouillet, E.; Luthi-Carter, R.; Hantraye, P.; et al. Sustained effects of nonallele-specific Huntingtin silencing. Ann. Neurol. 2009, 65, 276-285.

199. Boudreau, R.L.; McBride, J.L.; Martins, I.; Shen, S.; Xing, Y.; Carter, B.J.; Davidson, B.L. Nonallele-specific silencing of mutant and wild-type huntingtin demonstrates therapeutic efficacy in Huntington's disease mice. Mol. Ther. J. Am. Soc. Gene Ther. 2009, 17, 1053-1063.

200. Grondin, R.; Kaytor, M.D.; Ai, Y.; Nelson, P.T.; Thakker, D.R.; Heisel, J.; Weatherspoon, M.R.; Blum, J.L.; Burright, E.N.; Zhang, Z.; et al. Six-month partial suppression of Huntingtin is well tolerated in the adult rhesus striatum. Brain J. Neurol. 2012, 135, 1197-1209.

201. McBride, J.L.; Pitzer, M.R.; Boudreau, R.L.; Dufour, B.; Hobbs, T.; Ojeda, S.R.; Davidson, B.L. Preclinical safety of RNAi-mediated HTT suppression in the rhesus macaque as a potential therapy for Huntington's disease. Mol. Ther. J. Am. Soc. Gene Ther. 2011, 19, 2152-2162.

202. Olson, S.D.; Kambal, A.; Pollock, K.; Mitchell, G.-M.; Stewart, H.; Kalomoiris, S.; Cary, W.; Nacey, C.; Pepper, K.; Nolta, J.A. Examination of mesenchymal stem cell-mediated RNAi transfer to Huntington's disease affected neuronal cells for reduction of huntingtin. Mol. Cell. Neurosci. 2012, 49, 271-281.

203. Lu, Y.; Christian, K.; Lu, B. BDNF: A key regulator for protein synthesis-dependent LTP and long-term memory? Neurobiol. Learn. Mem. 2008, 89, 312-323. 
204. Bothwell, M. Functional interactions of neurotrophins and neurotrophin receptors. Annu. Rev. Neurosci. 1995, 18, 223-253.

205. Mizuno, K.; Carnahan, J.; Nawa, H. Brain-derived neurotrophic factor promotes differentiation of striatal GABAergic neurons. Dev. Biol. 1994, 165, 243-256.

206. Nakao, N.; Brundin, P.; Funa, K.; Lindvall, O.; Odin, P. Trophic and protective actions of brain-derived neurotrophic factor on striatal DARPP-32-containing neurons in vitro. Brain Res. Dev. Brain Res. 1995, 90, 92-101.

207. Zala, D.; Benchoua, A.; Brouillet, E.; Perrin, V.; Gaillard, M.-C.; Zurn, A.D.; Aebischer, P.; Déglon, N. Progressive and selective striatal degeneration in primary neuronal cultures using lentiviral vector coding for a mutant huntingtin fragment. Neurobiol. Dis. 2005, 20, 785-798.

208. Canals, J.M.; Pineda, J.R.; Torres-Peraza, J.F.; Bosch, M.; Martín-Ibañez, R.; Muñoz, M.T.; Mengod, G.; Ernfors, P.; Alberch, J. Brain-derived neurotrophic factor regulates the onset and severity of motor dysfunction associated with enkephalinergic neuronal degeneration in Huntington's disease. J. Neurosci. 2004, 24, 7727-7739.

209. California's Stem Cell Agency. MSC Engineered to Produce BDNF for the Treatment of Huntington's Disease. Available online: http://www.cirm.ca.gov/node/9662/review (accessed on 22 November 2013).

210. University of California, Davis. A Pre-Cellular Therapy Observational Study in Early Huntington's Disease Available online: http://clinicaltrials.gov/ct2/show/NCT01937923 NLM Identifier: NCT01937923 (accessed on 22 December 2013).

211. Glavaski-Joksimovic, A.; Bohn, M.C. Mesenchymal stem cells and neuroregeneration in Parkinson's disease. Exp. Neurol. 2013, 247, 25-38.

212. Olson, S.D.; Pollock, K.; Kambal, A.; Cary, W.; Mitchell, G.-M.; Tempkin, J.; Stewart, H.; McGee, J.; Bauer, G.; Kim, H.S.; et al. Genetically engineered mesenchymal stem cells as a proposed therapeutic for Huntington's disease. Mol. Neurobiol. 2012, 45, 87-98.

213. Lescaudron, L.; Boyer, C.; Bonnamain, V.; Fink, K.D.; Lévêque, X.; Rossignol, J.; Nerrière-Daguin, V.; Malouet, A.C.; Lelan, F.; Dey, N.D.; et al. Assessing the potential clinical utility of transplantations of neural and mesenchymal stem cells for treating neurodegenerative diseases. Methods Mol. Biol. 2012, 879, 147-164.

214. Allen, S.J.; Watson, J.J.; Shoemark, D.K.; Barua, N.U.; Patel, N.K. GDNF, NGF and BDNF as therapeutic options for neurodegeneration. Pharmacol. Ther. 2013, 138, 155-175.

215. Potts, M.B.; Silvestrini, M.T.; Lim, D.A. Devices for cell transplantation into the central nervous system: Design considerations and emerging technologies. Surg. Neurol. Int. 2013, 4, S22-S30.

216. Philippe, B.; Luc, S.; Valérie, P.-B.; Jérôme, R.; Alessandra, B.-R.; Louis, C. Culture and use of mesenchymal stromal cells in phase I and II clinical trials. Stem Cells Int. 2010, doi:10.4061/2010/503593.

217. Sensebé, L.; Bourin, P.; Tarte, K. Good manufacturing practices production of mesenchymal stem/stromal cells. Hum. Gene Ther. 2011, 22, 19-26.

(C) 2014 by the authors; licensee MDPI, Basel, Switzerland. This article is an open access article distributed under the terms and conditions of the Creative Commons Attribution license (http://creativecommons.org/licenses/by/3.0/). 